\title{
Hormone-receptor expression and survival patterns in operated cases of female invasive ductal breast carcinoma in Kerala: a retrospective cohort study
}

\author{
Ajith Vettuparambil ${ }^{1 *}$, Ravindran Chirukandath', Terence B Culas ${ }^{1}$, Sajna Mathumkunnath Vijayan², \\ Gautham Rajan ${ }^{3}$ and Sathidevi Vadakkepura Kuttappan ${ }^{4}$
}

\begin{abstract}
Background: Though breast cancer is the most common cancer among women in Kerala, India, epidemiological data on breast cancer in the state is largely lacking. The objectives of this study were to analyze the survival pattern of female breast carcinoma in this region of the country and to compare the differences in survival with different hormone-receptor expressions.

Methods: One hundred eighty-nine female breast cancer patients who were operated between 1 August 2008 and 3 July 2009 were followed up over telephone to obtain data on five-year survival. Grade, stage of the disease, and hormone-receptor (HR) status were obtained from treatment records. Logistic regression and the Kaplan-Meier survival analysis were used for statistical analysis.

Results: The mean age of the study population was 49.07 (SD, 10.35) years. A majority of the patients had estrogen receptor (ER)+/progesterone receptor (PR) + tumors ( $n=103,54.5 \%)$, followed by 72 (38.1\%) ER-/PR-, 10 (5.3\%) ER-/PR+, and 4 (2.1\%) ER+/PR-. Stage of the disease, axillary nodal status, and hormone-receptor status showed statistically significant association with overall survival in breast cancer. Overall survival rate at the end of 5 years was $71.4 \%$. Mortality was found to be highest for the ER - PR - group (47.2\%).

Conclusions: Women in Kerala are diagnosed with breast carcinoma at a relatively younger age, yet the overall five-year survival for the disease is low when compared to developed nations. It is imperative that comprehensive breast cancer screening and treatment strategies be developed to enable earlier diagnosis and improve the survival of breast cancer in the state.
\end{abstract}

Keywords: Hormone receptor, Survival, Breast cancer, Kerala, India

\section{Background}

Breast cancer is the most common cancer among women in many regions of India [1-3]. It is highly heterogeneous, with a wide range of biological, pathological, and clinical characteristics [4]. Among these, hormone receptors (estrogen receptor (ER), progesterone receptor (PR)) greatly influence clinical outcome, and their role as a prognostic and therapeutic tool is widely accepted

\footnotetext{
* Correspondence: ajitvl@gmail.com

'Department of General Surgery, Government Medical College, Thrissur, Kerala 680596, India

Full list of author information is available at the end of the article
}

[5,6]. Though the incidence of breast cancer in Kerala has been steadily mounting, data on epidemiology and survival of breast cancer in the state is scarce.

The objectives of this study were to analyze the survival pattern of female breast carcinoma in this region of the country and to compare the differences in survival with different hormone-receptor expressions.

\section{Methods}

A retrospective cohort study was conducted on 189 female patients who were diagnosed with invasive ductal carcinoma and had undergone surgery between 1 August

\section{Ciomed Central}


2008 and 31 July 2009 in the Department of General Surgery, Government Medical College, Thrissur. The required information was collected from the treatment records of the patients maintained at the Medical Records Library. All data including age, menopausal status, and pathological characteristics [grade (modified BloomRichardson grade), stage of the disease (AJCC), tumor size, and axillary nodal status] were recorded. Patients whose hormone-receptor status was not analyzed were excluded from the study. Patients who had either ER or PR positive tumors were treated with hormonal therapy. Overall survival was calculated in months, either from the date of diagnosis or from the date of surgery up to $31 \mathrm{De}$ cember, 2013. Five-year survival at the end of the study period was obtained from follow-up records for those who were on regular follow-up and was confirmed by contacting the patients or their relatives over telephone. Those who had been lost to follow-up were also traced over telephone.

All post-mastectomy specimens were evaluated for hormone-receptor expression (ER and PR) by immunohistochemistry. In accordance with the American Society of Clinical Oncology (ASCO) guidelines [7], which were being followed when the assays were done, specimens in which more than $10 \%$ of the tumor-nuclei stained positive were reported hormone-receptor positive. ER status was determined using the BioGenex monoclonal mouse IgG (Clone 1D5) (BioGenex, USA), and PR status was determined using BioGenex monoclonal mouse IgG (Clone 1A6) (BioGenex, USA). Antigen retrieval was done using the BioGenex EZ-Retriever system (BioGenex, USA). Based on hormone-receptor expression, patients were grouped into four categories, that is, $E R+P R+(E R$ positive PR positive), ER + PR-(ER positive PR negative), $\mathrm{ER}-\mathrm{PR}+$ (ER negative $\mathrm{PR}$ positive), and ER - PR-(ER negative PR negative).

Pathologic variables were compared using chi-square test. Logistic regression analysis was carried out to assess the independent association between different variables and survival. The Kaplan-Meier method was used to estimate the overall survival.

\section{Results}

One hundred eighty-nine female patients with invasive ductal breast cancer were included in the study. The age of the patients ranged from 27 to 80 with a median of $49.07 \pm 10$ years. ER expression was seen in 107 patents (56.6\%) and PR expression in 113 patients $(59.8 \%)$.

\section{General characteristics}

The general characteristics of the study group are shown in Table 1. Out of the 189 patients, 111 (58.7\%) were pre-menopausal. One hundred twenty-seven patients
Table 1 General characteristics of the study population

\begin{tabular}{llll}
\hline Variable & & $\boldsymbol{N}$ (number) & $\%$ \\
\hline Menopausal & Pre-menopausal & 111 & \\
& Post-menopausal & 78 & 48.73 \\
Grade & I & 13 & 6.27 \\
& II & 104 & 55 \\
Stage & III & 72 & 38.1 \\
& I & 11 & 5.8 \\
& II & 127 & 67.2 \\
& III & 51 & 27
\end{tabular}

Tumor size

$\begin{array}{lll}\mathrm{T} 1 & 14 & 7.4 \\ \mathrm{~T} 2 & 120 & 63.2 \\ \mathrm{~T} 3 & 34 & 17.9 \\ \mathrm{~T} 4 & 21 & 11.1\end{array}$

ER status

$\begin{array}{lll}\text { ER+ } & 107 & 56.61 \\ \text { ER- } & 82 & 43.39\end{array}$

PR status

$\begin{array}{lll}\text { PR+ } & 113 & 60 \\ \text { PR- } & 76 & 40\end{array}$

Hormone-receptor status

\begin{tabular}{lll}
$E R+P R+$ & 103 & 54.5 \\
$E R+P R-$ & 4 & 2.1 \\
$E R-P R+$ & 10 & 5.3 \\
$E R-P R-$ & 72 & 38.1 \\
\hline
\end{tabular}

(67.2\%) were between 41 and 60 years of age. Distribution of patients according to their age and hormone-receptor expression is shown in Table 2. A majority $(n=127$, $67.2 \%)$ had stage 2 breast cancer at presentation. One hundred four patients (55\%) had grade 2 tumor, and 120 (63.2\%) had tumor size between 2 and $5 \mathrm{~cm}$.

\section{Hormone-receptor expression and outcome}

In this breast cancer cohort, 103 patients (54.5\%) were $\mathrm{ER}+\mathrm{PR}+, 72$ patients (38.1\%) were ER - PR-, 10 patients (5.3\%) were ER - PR+, and 4 patients (2.1\%) ER + PR-. Mean follow-up time was 52 months. $71.4 \%$ of the patients $(n=135)$ were found to have survived to five years from the time of diagnosis. Mortality was found to be highest for the ER - PR - group ( $n=38,47.2 \%)$. Data regarding the four types of hormone-receptor expression and the outcomes of patents that belonged to each group is shown in Figure 1. Among the different age groups, patients aged 50 years or younger were found to have a higher mortality (Table 2). The Kaplan-Meier survival curve was 
Table 2 Distribution of patients according to their age and HR expression and their outcome

\begin{tabular}{|c|c|c|c|c|c|c|}
\hline Age group & $\begin{array}{l}\text { Total } \\
N\end{array}$ & $\begin{array}{l}\text { ER + PR+ } \\
N(\%)\end{array}$ & $\begin{array}{l}\text { ER + PR- } \\
N(\%)\end{array}$ & $\begin{array}{l}\text { ER - PR+ } \\
N(\%)\end{array}$ & $\begin{array}{l}\text { ER - PR- } \\
N(\%)\end{array}$ & $\begin{array}{l}\text { Survival } \\
N(\%)\end{array}$ \\
\hline 21 to 30 & 5 & $1(20)$ & 0 & 0 & $4(80)$ & $1(20)$ \\
\hline 31 to 40 & 36 & $23(63.8)$ & $1(2.78)$ & $3(8.33)$ & $9(25)$ & $27(72.97)$ \\
\hline 41 to 50 & 79 & $46(58.23)$ & 0 & $2(2.53)$ & 31 (39.24) & $59(75.64)$ \\
\hline 51 to 60 & 48 & $20(41.67)$ & $3(6.25)$ & $5(10.42)$ & $20(41.66)$ & 35 (72.91) \\
\hline 61 to 70 & 16 & $10(62.5)$ & 0 & 0 & $6(37.5)$ & $11(68.75)$ \\
\hline 71 to 80 & 5 & $3(60)$ & 0 & 0 & $2(40)$ & $2(40)$ \\
\hline Total & 189 & 103 & 4 & 10 & 72 & \\
\hline
\end{tabular}

plotted for the different types of hormone-receptor expression and for overall survival (Figures 2 and 3 ).

Tables 3 and 4 show the association between different variables and survival in breast cancer. Stage of the disease (adjusted risk ratio (RR) 1.274), nodal status (adjusted RR 1.055), and hormone-receptor status (adjusted RR 2.859) showed statistically significant association with overall survival.

\section{Discussion}

Breast cancer is the most common cancer among urban women and second most common among rural women in India [1]. Breast cancer is a heterogeneous disease that can be classified into several subtypes on the basis of various clinical and pathological features [8]. Hormonereceptor (ER and PR) status is now routinely determined for all patients to assess the possibility of providing them specific adjuvant hormone therapy [6].

The median age of the study group was $49.07 \pm$ 10.35 years, which is very low compared to the USA, where the median age at diagnosis of breast cancer is 61 years [9-11]. This considerable difference can likely be due to the genetic, racial, and socioeconomic differences between the two populations.

Data from the study showed that $56.6 \%$ patients were $\mathrm{ER}+$ and $54.5 \%$ patients were $\mathrm{ER}+\mathrm{PR}+$. This is low when compared to data from the USA, where the overall ER positivity is reported to be $77 \%$ [10]. The findings are consistent with earlier studies from India [12-15]. We also have a higher proportion of ER - PR - tumors compared to the West. It has been noted that ER and PR expression in the study subjects increase with age. This is in concordance with earlier studies $[16,17]$. A greater number of ER - PR - tumors were seen in patients younger than 50 years of age.

Population-based studies on breast cancer in Bangalore [18] and Chennai [19] showed five-year survival rates of $42.3 \%$ and $48 \%$, respectively. The five-year survival rate of the current study cohort was much higher, at $71.43 \%$. The differences in the survival rate can be

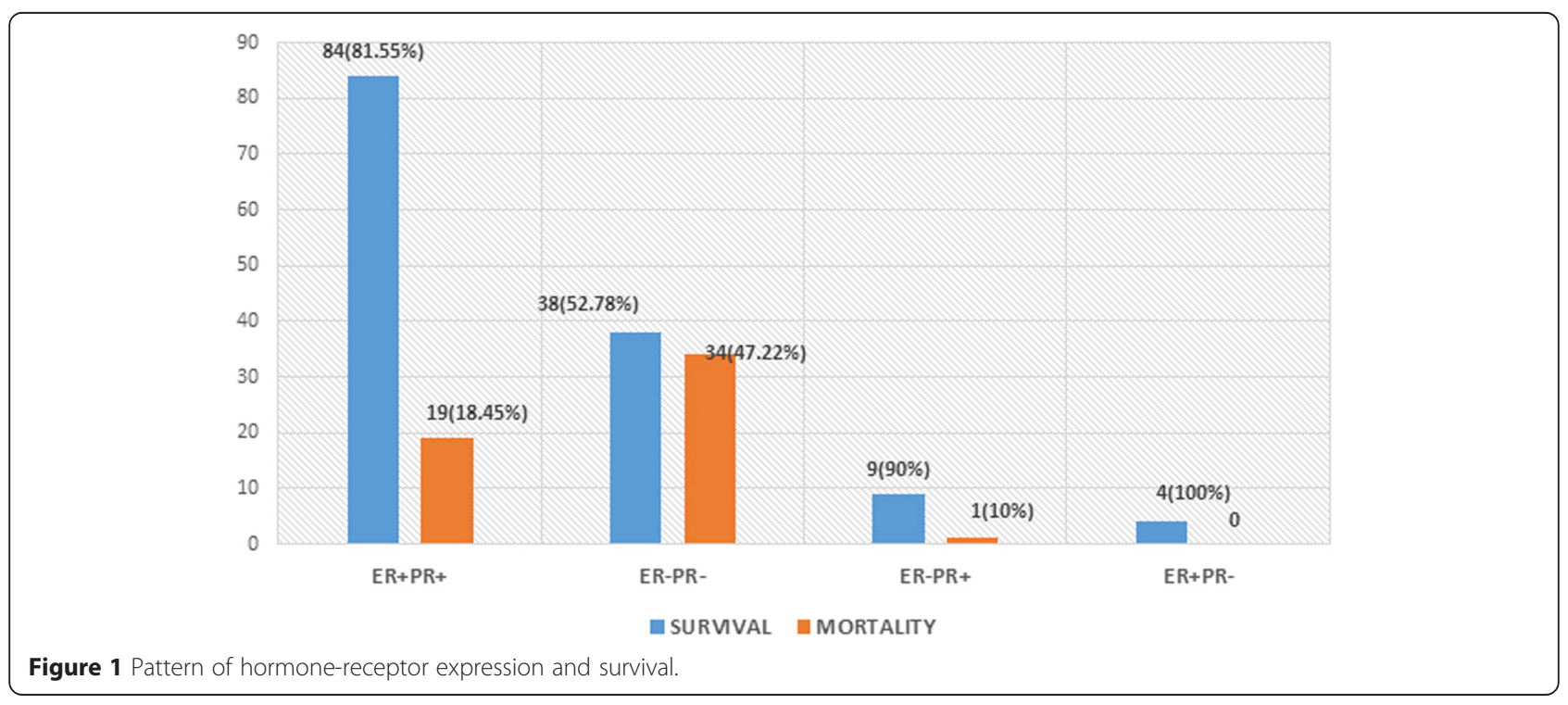




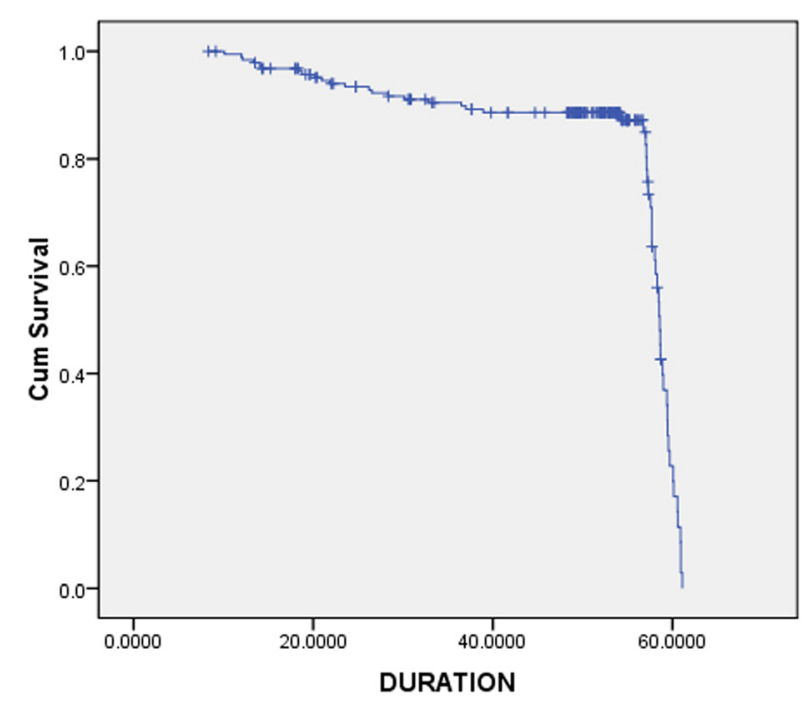

$\neg$ Survival Function

+ Censored

Figure 2 Kaplan-Meier Curve for overall survival.

explained by differences in the study settings. The USA has an average five-year survival rate of $89.2 \%$ for patients diagnosed with breast cancer [10]. The overall survival rate is still low compared to the West. Five-year survival rates of more than $80 \%$ have been reported in many studies from the West and also from a developed Asian country $[20,21]$. Ethnicity and race have been documented as important factors that influence the survival rate [22]. Along with these factors, well-established screening programs and early detection of the disease also help improve the survival rate.

$\mathrm{ER}+\mathrm{PR}+$ breast cancer has been independently associated with decreased breast cancer mortality in many studies $[4,19,23,24]$. A similar survival pattern was also noted in the current cohort, with highest mortality in the ER - PR - group.

Stage of the disease, axillary nodal status, and hormonereceptor status showed statistically significant association with overall survival in breast cancer. Among these, the axillary nodal status and stage of the disease are established prognostic factors for carcinoma breast [5,16]. Along with their proven role in determining therapeutic course, hormone receptors (ER and PR) can also be used as a predictive tool for breast cancer survival.

$\mathrm{ER}-\mathrm{PR}+$ is a rare subtype of breast cancer based on hormone-receptor expression that accounts for $1 \%$ to
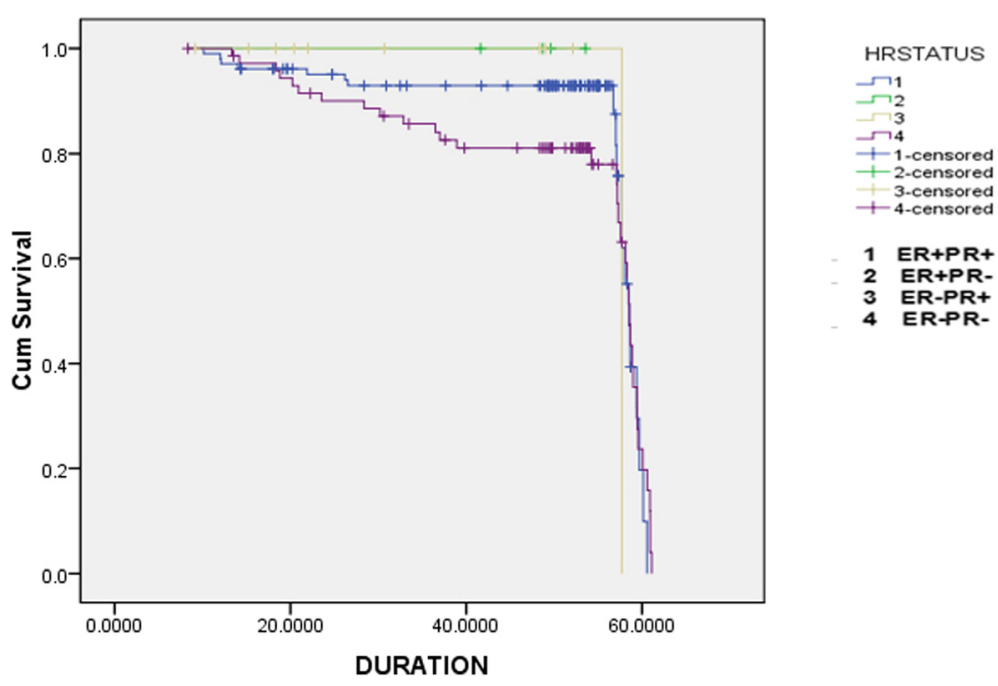

Figure 3 Kaplan-Meier Curve for survival for different hormone-receptor expression. 
Table 3 Association of different variables to survival of breast cancer (univariate analysis)

\begin{tabular}{ll}
\hline Pathological variables and other factors & $\boldsymbol{P}$ value \\
\hline Age & 0.083 \\
Menopausal status & 0.53 \\
Tumor size & 0.164 \\
Tumor grade & 0.084 \\
Stage & $<0.0001$ \\
Nodal status & 0.0001 \\
Hormone-receptor status & $<0.0001$ \\
Estrogen receptor & 0.000 \\
Progesterone receptor & 0.573 \\
\hline
\end{tabular}

$P$ value $<0.05$ significant.

$4 \%$ of all cases reported in literature [25]. The study cohort has a similar fraction of patients $(5.3 \%)$ with ER $\mathrm{PR}+$ expression, and $90 \%$ survival has been noted in this particular group. The predictive value of $\mathrm{PR}$ in the absence of ER expression is controversial [26,27]. Some reports suggest that positive PR in the absence of ER has a higher response to hormone therapy, but this finding is not universal [28-30]. Unfortunately, because of the relatively small number of patients in the study group who belonged to this subset, it is difficult to comment on the role of this particular type of receptor expression on disease outcome.

\section{Conclusions}

The overall five-year survival rate of breast cancer patients in Kerala is low compared to developed nations. The lack of an effective cancer screening program is an important reason for this. The higher proportion of hormone-receptor (HR)-negative tumors in our population may be due to delayed diagnosis along with other genetic, ethnic, and cultural variations. Since data on epidemiology and risk factors of the breast cancer in the state is inadequate, it is very crucial to further explore these aspects of the disease to develop a prevention and control strategy to improve the survival rate.

Table 4 Association of pathological variables and survival in invasive female ductal carcinoma (multilogistic regression analysis)

\begin{tabular}{llll}
\hline & \multirow{2}{l}{$\begin{array}{l}\text { Adjusted } \\
\text { RR }\end{array}$} & \multicolumn{2}{l}{$\mathbf{9 5 \%} \mathbf{C l}$ for adjusted RR } \\
\cline { 3 - 4 } & & Lower & Upper \\
\hline Tumor grade & 1.451 & 0.73 & 2.884 \\
Axillary nodal status & 1.393 & 1.055 & 2.571 \\
Stage of the disease & 1.958 & 1.274 & 3.007 \\
HR status & 2.859 & 0.962 & 10.733 \\
\hline
\end{tabular}

$\mathrm{RR}$ - risk ratio. Cox-Snell $R^{2} 0.271$

\section{Abbreviations}

HR status: Hormone-receptor status; ER: Estrogen receptor; PR: Progesterone receptor; RR: Risk ratio; ASCO: American Society of Clinical Oncology;

AJCC: American Joint Committee on Cancer.

\section{Competing interests}

The authors declare that they have no competing interests.

\section{Authors' contributions}

AVL participated in the study design, collected and interpreted data, and prepared the manuscript. RC was involved in the study design, coordinated the study, and revised the manuscript. TBC assisted with the study design, coordinated the study, and revised the manuscript. SMV helped in drafting the protocol, performed statistical analysis, and interpreted data. GR was involved in the preparation of the manuscript. SVK revised the manuscript. All authors read and approved the final manuscript.

\section{Acknowledgements}

The State Board of Medical Research, Kerala, India provided funds and support. Dr. Jayadev V K, assistant professor, Department of Community Medicine, helped with drafting the protocol. Achuth Ajith Kumar, Aarati Krishnan and Amitha Abraham, $27^{\text {th }}$ batch MBBS students, helped in data collection.

Funding

Funding was provided by the State Board of Medical Research, Kerala, India.

\section{Author details}

${ }^{1}$ Department of General Surgery, Government Medical College, Thrissur, Kerala 680596, India. ${ }^{2}$ Department of Community Medicine, Government Medical College, Thrissur, Kerala 680596, India. ${ }^{3}$ Government Medical College, Thrissur, Kerala 680596, India. ${ }^{4}$ Department of Anatomy (Epidemiology), Government Medical College, Thrissur, Kerala 680596, India.

Received: 11 November 2014 Accepted: 14 April 2015

Published online: 23 April 2015

\section{References}

1. Programme NCR. Consolidated Report of the Population based cancer registries 1990-1996. New Delhi: Indian Council of Medical Research; 2001.

2. Population based cancer registry, Biennial report, 2000 and 2001, 2002, Department of Epidemiology and Bio-Statistics, Kidwai Memorial Institute of Oncology, Bangalore, India, 2004 and 2005.

3. National Cancer Registry Programme. Ten year consolidated report of the hospital based cancer registries 1984-1993. In: An assessment of the burden and care of cancer patients. New Delhi: Indian Council of Medical Research; 2001.

4. Di CS, Baselga J. Management of breast cancer with targeted agents: importance of heterogenecity. Nat Rev Clin Oncol. 2010;7:139-47.

5. Fitzgibbons PL, Page DL, Weaver D, Thor AD, Craig Allred D, Clark GM, et al. Prognostic factors in breast cancer: College of American Pathologists Consensus Statement 1999. Arch Pathol Lab Med. 2000;124:966-78.

6. Rastelli F, Crispino S. Factors predictive of response to hormone therapy in breast cancer. Tumori. 2008;94:370-83.

7. Hammond MEH, Hayes DF, Dowsett M, Allred DC, Hagerty KL, Badve S, et al. ASCO-CAP guideline recommendations for immunohistochemical testing of estrogen and progesterone receptors in breast cancer. J Clin Oncol. 2010;28:2784-95

8. Blows FM, Driver KE, Schmidt MK, Broeks A, van Leewen FE, et al. Subtyping of breast cancer by immunohistochemistry to investigate a relationship between subtype and short and long term survival: a collaborative analysis of data for 10,159 cases from 12 studies. PlosMed. 2010;7(5):e 1000279.

9. Rhodes A, Jasani B, Balaton AJ, Barnes DM, Miller KD. Frequency of estrogen and progesterone receptor positivity by immunohistochemical analysis in 7016 breast carcinomas: correlation with patient age, assay sensitivity, threshold value, and mammographic screening. Clin Pathol. 2000;53:688-96.

10. SEER-Stat database [http://seer.cancer.gov/statfacts/html/breast.html]

11. Leong SPL, Shen ZZ, Liu TJ, Agarwal G, Tajima T, Paik N, et al. Is breast cancer the same disease in Asian and western countries? World J Surg. 2010;34:2308-24 
12. Rashmi K, Jaishree S, Satinder SM, Kavita M. Hormone receptor status of breast cancer in the Himalayan region of Northern India. Indian J Surg Oncol. 2011;73(1):9-12.

13. Dey S, Boffetta P, Mathews A, Brennan P, Soliman A, Mathew A. Risk factors according to estrogen receptor status of breast cancer patients in Trivandrum South India. Int J Cancer. 2009;125(7):1663-70.

14. Shet T, Agrawal A, Nadkarni M, Palkar M, Havaldar R, Parmar V, et al. Hormone receptors over the last 8 years in a cancer referral centre in India:what was and what is? Indian J Pathol Microbiol. 2009;52(2):171-4.

15. Manjunath S, Jyothi SP, Rohini K, Marjorie C, Sridhar TS. Estrogen receptor negative breast cancer in India: do we really have higher burden of this subtype? Indian J Surg Oncol. 2011;2(2):122-5.

16. Dunnwald LK, Rossing MA, Li Cl. Hormone receptor status, tumor characteristics, and prognosis: a prospective cohort of breast cancer patients. Breast Cancer Res. 2007;9:R6.

17. Azizun-Nisa Bhurgri Y, Raza F, Kayani N. Comparison of ER, PR and HER-2/neu (C-erb B 2) reactivity pattern with histologic grade, tumor size and lymph node status in breast cancer. Asian Pac J Cancer Prev. 2008:9:553-6.

18. Murthy NS, Agarwal UK, Chaudhry K, Saxena S. A study on time trends in incidence of breast cancer-Indian scenario. Eur J Cancer Care. 2007;16:185-6.

19. Gajalakshmi CK, Shanta V, Swaminathan R, Sankaranarayanan R, Black RJ. A population-based survival study on female breast cancer in Madras India. $\mathrm{Br}$ J Cancer. 1997;75:771-5.

20. Berrino F, De Angelis R, Sant M, Rosso S, Bielska-Lasota M, Coebergh JW, et al. Survival for eight major cancers and all cancers combined for Europian adults diagonosed in1995-99: results of the EUROCARE-4 study. Lancet Oncol. 2007:8:773-83.

21. Tsukuma H, Ajiki W, loka A, Oshima A. Research Group of Population-Based Cancer Registries of Japan. Survival of cancer patients diagnosed in 1993-1996: collaborative study of population-based cancer registries in Japan. Jpn J Clin Oncol. 2006;36:602-7.

22. Joslyn SA, West MM. Racial differences in breast carcinoma survival. Cancer. 2000:88:114-23.

23. Anderson WF, Chu KC, Chatterjee N, Brawely O, Brinton LA. Tumor variants by hormone receptor expression in white patients with node negative breast cancer from the surveillance, epidemiology, and end result data base. J Clin Oncol. 2001;19:18-27.

24. Pichon MF, Broet P, Magdelenat H, Delarue JC, Spyratos F, Basuyau JP, et al. Prognostic value of steroid receptors after long term follow up of 2257 operable breast cancers. Br J Cancer. 1996;73:1545-51.

25. Navani S, Bhaduri AS. High incidence of estrogen receptor negative progesterone receptor positive phenotypes in breast cancer: fact or fiction? Indian J Pathol Microbiol. 2005;48(2):199-201.

26. Rhodes A, Jasani B. The oestrogen receptor-negative/progesterone receptor-positive breast tumour: a biological entity or a technical artefact? J Clin Pathol. 2009;62:95-6.

27. De Maeyer L, Van Limbergen E, De Nys K, Moerman P, Pochet N, Hendrickx $W$, et al. Does estrogen receptor negative/progesterone receptor positive breast carcinoma exist? J Clin Oncol. 2008;26:335-6.

28. Bardou VJ, Arpino G, Elledge RM, Osborne CK, Clark GM. Progesterone receptor status significantly improves outcome prediction over estrogen receptor alone for adjuvant endocrine therapy in two large breast cancer data bases. J Clin Oncol. 2003;21:1973-9.

29. Early Breast Cancer Trialists' Collaborative Group. Tamoxifen for early breast cancer: an overview of the randomized trials. Lancet. 1998;35:1451-67.

30. Olivotto IA, Truong PT, Speers CH, Bernstein V, Allan SJ, Kelly SJ, et al. Time to stop progesterone receptor testing in breast cancer management. J Clin Oncol. 2004;22:1769-70.

\section{Submit your next manuscript to BioMed Central and take full advantage of:}

- Convenient online submission

- Thorough peer review

- No space constraints or color figure charges

- Immediate publication on acceptance

- Inclusion in PubMed, CAS, Scopus and Google Scholar

- Research which is freely available for redistribution 